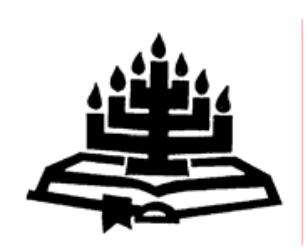

\title{
Respons op Die dood van die outeur en die inspirasie van die Bybel: in gesprek met P.J. Nel en S.D. Snyman
}

\author{
S.D. (Fanie) Snyman \\ Departement Ou Testament \\ Universiteit van die Vrystaat \\ BLOEMFONTEIN \\ E-pos: snymansd.hum@mail.uovs.ac.za
}

\begin{abstract}
Response to The death of the author and the inspiration of the Bible: in discussion with P.J. Nel and S.D. Snyman

This contribution is a response to an article that enters into a debate with an earlier article by the present author published in 2003, where it was argued that current theories on the inspiration of the Bible can no longer be maintained due to our knowledge of the origin of especially the Old Testament. In this response it is argued that the arguments put forward as a critique of the earlier article are not convincing. Arguments against current theories of the inspiration of the Bible are taken note of, but they are not countered for. Furthermore, some of the arguments are simply ignored. The status quo seems to be the answer proposed.
\end{abstract}

\section{Opsomming}

Respons op Die dood van die outeur en die inspirasie van die Bybel: in gesprek met P.J. Nel en S.D. Snyman

Hierdie artikel is 'n respons op 'n artikel wat in debat tree met 'n vroeëre artikel van die outeur wat in 2003 gepubliseer is. In daardie artikel is geargumenteer dat huidige inspirasieteorieë van die Bybel ontoereikend is as gevolg van ons kennis van die ontstaan van spesifiek die Ou Testament. In hierdie respons word geargumenteer dat kritiek teen die vroeëre artikel nie ootuigend is nie. Argumente teen die huidige inspirasieteorieë van die Bybel word erken, maar word nie weerlê nie. Verder word ander argumente geïgnoreer. Die status quo bly dus die antwoord. 


\section{Inleiding}

In die Desember 2005-uitgawe van In die Skriflig publiseer Verster (2005:715-732) 'n artikel waarin hy in gesprek tree met standpunte van prof. P.J. Nel (2003:881-897) en myself. Die standpunte wat Verster in die artikel stel, noodsaak my om te reageer. In sy artikel tree Verster ook in debat met prof. P.J. Nel, maar ek beperk my in my reaksie tot Verster se opmerkings oor standpunte wat ek gestel het. Hierdie artikel is dus 'n respons op kritiek wat Verster uitspreek op 'n artikel van my wat in 2003 gepubliseer is (Snyman, 2003:459473).

\section{Die problematiek van bestaande inspirasieteorieë}

Ter wille van duidelikheid en sonder om lesers bloot terug te verwys na die artikel waarteen Verster dit het, bied ek 'n kort, kursoriese opsomming aan van die argument wat ek daar gevoer het. Die volledige artikel kan self nagegaan word (Snyman, 2003:459-473).

Die problematiek wat behandel word, is die vraag of daar binne gereformeerde dogmatiek volstaan kan word met bestaande teorieë oor die inspirasie van die Bybel. Die argument wat gevoer word, is dat bestaande teorieë oor die inspirasie van die Bybel ontoereikend is en dat daar ruimer gedink moet word in terme van die inspirasie van die Bybel (Snyman, 2003:461).

Hierdie standpunt word beredeneer vanuit verskillende perspektiewe. Wie die Bybel noukeurig lees, kom gou agter dat die Bybelskrywers mense was, mense wat in 'n bepaalde historiese tydgleuf gelewe het en wie se voorkeure en oortuigings gesien kan word in die tekste wat geskryf is. Verder moet ons ook erken dat ons as hedendaagse Bybellesers geen toegang het tot die proses van inspirasie nie. Gevolglik weet ons nie werklik wat gebeur het tussen die Bybelskrywers en die Heilige Gees nie (Snyman, 2003:462-463). Die bekende teksverse van 2 Timoteus 3:16 en 2 Petrus 1:21 help ook nie regtig in hierdie verband nie.

In die lig van ons kennis oor die lang proses van mondelinge oorlewering, eerste opskrifstellings van mondelinge oorlewering, uitbreidings, weglatings, rangskikking en herrangskikking van die stof, die tot stand kom van 'n gevokaliseerde Hebreeuse teks, die voorkoms van 'n verskeidenheid manuskripte, is die vraag waar inspirasie eintlik begin. Dit is ook ' $n$ vraag waar inspirasie eindig. Is dit net die Hebreeuse manuskrip(te) wat geïnspireer is, of is die Septuaginta waaruit so dikwels in die Nuwe Testament aangehaal 
word as Woord van God ook geïnspireer? As hierdie vertaling geïnspireer is, geld dit nie ook vir ander vertalings nie? Die vraag is dus nie net waar inspirasie begin nie, maar ook waar dit eindig (Snyman, 2003:465-467).

Die bestaan van verskillende kanons - die Hebreeuse, Griekse, Rooms-Katolieke en Protestantse kanons - kompliseer die vraag na die inspirasie verder. Die oplossing wat aan die hand gedoen word, is dat daar ruimer gedink moet word oor inspirasie, sodat inspirasie nie alleen die totale proses van kanonvorming moet insluit nie, maar ook die vertaling én die verkondiging van die Woord (Snyman, 2003:468-471). Uiteindelik word daar tot die gevolgtrekking gekom dat die inspirasie van die Bybel deur die Heilige Gees nie bewys kan word nie en ook nie bevredigend in 'n teorie deurgrond, verduidelik of omskryf kan word nie - dit kan eintlik net bely word (vgl. NGB Art. 3; Snyman, 2003:472).

\section{In gesprek met Verster}

\subsection{Die goddelike element onderspeel?}

Vir Verster word die goddelike element in die Bybel onderspeel en die menslike aspek só sterk beklemtoon dat 'n mens nie meer kan sê dat God as die auctor primarius opgetree het nie (Verster, $2005: 724,726)$. Volgens Verster (2005:726) is daar 'n duidelike verskil tussen die goddelike werking deur die Gees, waar Hy sekere aspekte van die Skrif in ons verhelder en die voorrang van die inspirasie, wat direk met teopneustie in verband gebring word en waar God direk by die Skrif betrokke is.

Verster laat egter na om die "duidelike" verskil duidelik aan te toon. Is die verligting deur die Gees daar waar net sekere (watter?) aspekte van die Skrif in ons verhelder word dan 'n minder direkte (en dus indirekte) manier en gevolglik ook 'n minderwaardige manier waarop God deur dieselfde Gees met sy Woord werk? Is dit nie 'n kunsmatige skeiding wat mense uitgedink het nie?

Verster (2005:727) se vraag is: Is daar geen moontlikheid om die goddelike oorsprong van die Bybel te erken nie? Interessant genoeg vorm dié vraag 'n opskrif in 'n subparagraaf van sy artikel. Die subparagraaf bestaan uit tien sinne waarvan ses in vraagvorm gestel word. Verster vra die vraag, maar gee nie eintlik 'n antwoord op die vraag wat hy vra nie. Die vraag van Verster is egter nie die punt van my betoog nie. Dit is nie die goddelike oorsprong van die Bybel wat bevraagteken word nie. Wat bevraagteken word, is 
heersende teorieë wat die goddelike oorsprong van die Bybel probeer verklaar en verduidelik en wat intussen ontoereikend geword het. Om die menslike dimensie in die Bybel ernstig op te neem, is nie gelyk aan 'n onderwaardering of onderspeling van die goddelike dimensie van die Bybel nie. Die feit is dat ons die Bybel nie anders kan lees en interpreteer as 'n bundel literatuur in menslike taal, wat deur mense geskryf is wat in konkrete tydgleuwe van die geskiedenis geleef het nie. Wat hulle geskryf het oor die tyd heen, is God se openbaring aan ons. Die teendeel is 'n bedenklike manier om die Bybel te lees, waar die Bybel 'n boek word wat "zenkrecht von oben" uit die hemel self neergedaal het en nou direk met ons praat, ontdaan van sy (soms al te lastige) menslike aspek.

\section{2 'n Oop kanon?}

Verster (2005:727) vra of die Bybel as teks anders is as vertaling, as die uitbreiding van die teks en as die prediking van die teks. Die uiteindelike gevolg van so 'n standpunt is volgens Verster, dat die gevaar van 'n oop kanon 'n werklikheid word.

Oor die gevaar van 'n oop kanon waarop Verster wys, is my indruk dat daar weinig of geen debat oor die kwessie van 'n oop kanon al dan nie, is nie. Die breë konsensus is dat die Bybel 'n klassieke werk is waaraan daar geen toevoegings gemaak (hoef te) word nie. Selfs nie eers die onlangse bekendstelling en publikasie van die evangelie van Judas met al die publisiteit wat daarmee gepaard gegaan het, het die debat oor die kwessie van 'n oop kanon al dan nie, geopen nie.

\subsection{Nogeens 2 Timoteus 3:16 en 2 Petrus 1:21}

Verster (2005:727) beweer verder "Snyman se eksegese oortuig nie", terwyl hy terselfdertyd erken dat daar probleme met die interpretasie van die teks is. In alle billikheid moet gesê word dat daar nie 'n eksegese van die betrokke tekste in die artikel aangebied is nie. Wat wel gedoen is, is om die interpretasieprobleme in veral 2 Timoteus 3:16 bloot te lê en met aanhalings uit 'n paar kommentare aan te toon dat die konsensus in baie kommentare is dat om 'n inspirasieteorie uit die teks af te lei, 'n oorspanning van die teks se seggingskrag is. Wat wel gesê word, is dat die tekste 'n verband lê tussen God en die Woord, 'n verband wat deur die Heilige Gees gelê word. Hoe Verster daarby uitkom om te sê dat daar in 2 Timoteus 3:16 "reeds 'n erkenning is dat God op 'n baie unieke wyse met sekere bronne (ons weet nie presies watter nie) gewerk het om die grondteks geïnspireerd tot stand te bring" 
(Verster, 2005:727), is moeilik om te begryp en kom neer op 'n oorspanning van die seggingskrag van die teks. Met watter bronne sou God gewerk het, aangesien ons volgens Verster se eie erkenning nie weet met presies watter bronne God sou gewerk het nie? Ek vind geen aanduiding in die teks van 2 Timoteus 3:16 dat God hoegenaamd van bronne sou gebruik gemaak het om 'n geïnspireerde teks tot stand te bring nie.

Verster is van mening dat ek Guthrie (1981:970) verkeerd verstaan (Verster, 2005:728). In die volgende sin van sy artikel gee hy my egter gelyk, as hy erken dat Guthrie 'n meganistiese inspirasieteorie afwys en ook nie 'n bepaalde teorie uit die teks wil aflei nie. Dit is presies die argument wat ek voer en ek haal vir Guthrie ter ondersteuning hiervan aan! My argument is nie teen die goddelike oorsprong van die Bybel nie en daar is ek dit met Guthrie eens (Snyman, 2003:465). My argument is dat 'n mens nie 'n inspirasieteorie uit 2 Timoteus 3:16 kan aflei nie.

\subsection{Die grondteks van die Ou Testament?}

'n Term wat Verster $(2005: 727,730)$ meermale gebruik, is die term grondteks of ook bronteks. Die vraag wat aan Verster gestel word, is na watter teks van die Bybel hy verwys? Is daar net één oorspronklik geïnspireerde teks? 'n Mens kry die indruk dat Verster met hierdie veronderstelling werk as hy beweer: "Die gedagte dat die grondteks wel op 'n unieke wyse deur God geïnspireer is, sluit aan by 2 Timoteus 3:16 en 2 Petrus 1:21, 22" (Verster, 2005:727). Indien dit wel die geval is, watter grondteks is geïnspireer? In die wetenskap van die Ou-Testamentiese tekskritiek is dit 'n vraag of daar hoegenaamd net één oorspronklike oerteks was waarheen alle ander tekste terugherlei kan word. Selfs al word aanvaar dat daar net een oorspronklike oerteks was, is daardie teks nie meer tot ons beskikking nie. Ons beskik nie meer oor die autographa van die verskillende Bybelboeke nie. Al wat ons vandag het, is afskrifte van afskrifte, van afskrifte, van afskrifte ... As Verster van mening is dat dit net die grondteks of bronteks (terme wat hy gebruik) is wat geïnspireer is, is dit 'n vraag of ons vandag dan nog hoegenaamd kan aanspraak maak op 'n geïnspireerde Bybel, want die Bybel wat ons het is die produk van waarskynlik baie tekste. Trouens, die tans gangbare Hebreeuse teks van die Ou Testament wat gebruik word, dateer uit 1008/1009 n.C. en die rede waarom die teks gebruik word, is bloot omdat dit die oudste(!) volledige manuskrip van die Hebreeuse Ou Testament is waaroor ons beskik (Elliger \& Rudolph, 1984:x). 
Die Bybel van die vroeë kerk was die Griekse vertaling van die Ou Testament wat, soos ons weet, plek-plek weglatings en byvoegings van en tot die Hebreeuse teks van die Ou Testament bevat. Vir baie jare was die enigste Bybel vir die kerk die Vulgaat. Moet ons nou tot die gevolgtrekking kom dat die kerk in die belangrike eerste jare van haar bestaan en vir eeue daarna met 'n inspirasielose Bybel ('n contradictio in terminis?) gesit het? Die argument wat ek voer is juis dat in die lig van hierdie en ander gegewens, ons die proses van inspirasie moet uitbrei om méér in te sluit as net 'n oorspronklike, eenmalig geïnspireerde grondteks.

\subsection{Predicatio verbi Dei est verbum Deil}

Volgens Verster (2005:728) verstaan ek Calvyn nie korrek waar ek hom aanhaal om die hoë waarde wat hy aan die verkondiging van die Woord heg, te illustreer nie. In Boek 4 handel Calvyn oor die sleutelmag van die kerk en dit is juis binne hierdie konteks waar hy die hoë premie plaas op die Woord wat verkondig word. Vir Calvyn kom die sleutelmag wat aan die kerk toevertrou word neer op "de dienst des Woords, welke de Here aan de apostelen zo toevertrouwde ..." (Calvyn, Boek IV, Hoofstuk XI:1, 237). Dit (die sleutelmag) is "de hoofdinhoud van het evangelie", wat niks anders is as "dat wij allen, die dienstknechten zijn der zonde en des doods, ontbonden en bevrijd worden door de verlossing, die is in Christus Jezus". Wie Christus as Verlosser en Saligmaker nie aanneem en erken nie "tot eeuwige banden zijn veroordeeld en verwezen". Dit alles gebeur deur die prediking van die apostels (Calvyn, Boek IV, Hoofstuk Xl:1, 237). Die hoorders van die prediking van die apostels moes ook "volkomen zeker betuigd zijn dat die leer des evangelies niet het woord der apostelen was, maar van God self, niet een stem, geboren op aarde, maar neergedaald uit de hemel. Want deze dingen, namelijk de vergeving van zonden, de belofte des eeuwigen levens, en de boodschap der zaligheid, kunnen niet in de macht der mensen staan" (Calvyn, Boek IV, Hoofstuk XI:1, 237). Dit is binne dié konteks dat Calvyn dan vervolg deur te sê dat die Woord van die evangelie deur watter mens ook al verkondig, "de eigen uitspraak Gods is" (Calvyn, Boek IV, Hoofstuk XI:1, 238). Ek meen dat Verster nie billik oordeel oor my verstaan van Calvyn op hierdie punt nie. Dit is duidelik dat Calvyn hier die verkondiging van die evangelie bedoel.

Hierdie saak gaan egter verder as net Calvyn. Reeds in die Nuwe Testament is daar aanduidings van die hoë waarde wat geheg word aan die verkondigde Woord. In 1 Tessalonisense 2:13 staan: 
Ons dank God dan ook gedurig daarvoor dat julle die boodskap van God wat julle van ons gehoor het, ontvang en aangeneem het in die oortuiging dat dit nie mensewoorde is nie, maar die woord van God self. En dit is ook inderdaad die woord van God, soos die uitwerking daarvan op julle wat glo, bewys.

In menslike prediking word die Woord van God dus herken en vra Berkouwer (1967:398) in dié verband of dit nie juis die eerste en laaste woord in die besinning oor alle prediking is nie? Die belangrikheid van die verkondigde Woord word nie slegs hier beklemtoon nie. In die Ou Testament is groot dele van dit wat ons vandag op skrif het waarskynlik eers mondeling oorgelewer. Die profete verkondig hulle boodskap met die kenmerkende "so sê die Here" eers mondeling voordat dit later op skrif gestel word. Jesus se woorde word eers deur Homself uitgespreek voordat dit later skriftelik neerslag vind in die verskillende evangelies. Dit is interessant om op te merk dat Jesus self geen geskrif waarvan ons weet agtergelaat het nie. Petrus se preek op Pinksterdag word eers mondeling gelewer voordat dit later gelees kan word in Handelinge 2. In 2 Petrus 1:21 is daar ook sprake van die mense wat deur die Heilige Gees meegevoer is, wat die woord wat van God kom, verkondig en wat die klem dus ook laat val op die mondelinge verkondiging van die Woord.

Vandag is dit anders in 'n Westerse kultuur. Toesprake, preke, referate en lesings wat in die openbaar en mondeling gelewer word, word eers op skrif gestel en dan mondeling gelewer. Politici stel persverklarings beskikbaar aan die pers waarin daar staan wat hulle by wyse van ' $n$ mondelinge persverklaring bekend gaan maak. lets van die belangrikheid van die mondelingse lewering kry 'n mens nog steeds is die westerse papiergedrewe samelewing. Wanneer 'n politikus afwyk van sy geskrewe manuskrip en 'n paar woorde sê sonder 'n geskrewe weergawe daarvan, word dit gewoonlik in die media spesiaal vermeld.

Die aanhaling waarmee die opskrif hierbo begin, is ' $n$ aanhaling uit die Confessio Helvetica en Berkouwer (1967:398) wys op die merkwaardige est in die formulering. In die nadere verklaring van die est word die oortuiging uitgespreek dat die woorde van die prediker dieselfde is as die Woord van God (ipsum Dei verbum). Berkouwer (1967:400) vind dit verder begryplik dat daar in die Reformasie nie daartoe gekom is om die est te vervang met 'n meer relatiewe kwalifikasie soos byvoorbeeld quaetenus nie. Ek verwys hier ietwat meer breedvoerig na Berkouwer, omdat Verster (2005:728) Berkouwer aanhaal om my argument verkeerd te bewys. Na my 
oordeel lê my standpunt veel meer in ooreenstemming met die gereformeerde tradisie wat sy oorsprong in die Bybel vind en vandaar gekontinueer word in die kerk.

Theron (2002:152) wys in hierdie verband hoe die tradisie van die belangrikheid van en die hoë premie op die verkondigde Woord tipies is aan die Reformasie. Luther is byvoorbeeld bekend daarvoor dat hy 'n minagtende houding teenoor sy eie publikasies gehad het en dat hy van oortuiging was dat eintlik net twee van sy geskrifte (Die groot kategismus en Die onvryheid van die wil) verdien het om voort te bestaan. Volgens Luther moes die evangelie eintlik nie op skrif gestel word nie, maar alleen met die lewende stem verkondig word, vandaar sy oproep dat die kerk nie 'n penhuis is nie maar 'n mondhuis: "Sien Christus nie aan met $u$ oë nie, maar plaas $u$ oë in $u$ ore" (Theron, 2002:152). Theron vervolg dan: "God self kom in die prediking op ons af en spreek ons aan in die lewende stem van die prediker." "Alleen in die lewende, interpersoonlike verkondiging van die evangelie kom die lewende Woord lynreg op my af en word Gods oordeel en genade my toegesê" (Theron, 2002:152).

Nürnberger (1975:32) vra wie se woord ons in die prediking hoor, naamlik die Woord van God of die woord van die prediker. Dan antwoord hy: "Klaarblyklik is dit God se Woord, want niemand kan die Woord van God uitspreek behalwe God self in die krag van sy Heilige Gees nie! Maar ewe klaarblyklik is dit die prediker se woord" (Nürnberger, 1975:32).

\subsection{Tekste wat direk kommunikeer?}

Verster (2005:729-730) maak 'n vlugtige verwysing na fundamentalisme wat hy afwys, maar "[d]aar is egter talle tekste in die Bybel wat wel direk kommunikeer vanuit die teks self en wat nie as fundamentalistiese teksinterpretasie beskryf kan word nie omdat dit in ooreenstemming is met die teks self', verklaar Verster. Hierdie onderskeid wat Verster maak tussen tekste wat sogenaamd direk kommunikeer en ander tekste wat dit nie doen nie, is ' $n$ hoogs problematiese onderskeid. Die Bybel kom in die kleed van 'n bepaalde historiese ontstaanstyd. Dit is merkwaardig hoeveel keer daar in die Ou Testament melding gemaak word van 'n profesie of 'n ander uitspraak in die tyd van die regering van koning So en So van Israel of Juda. Groot dele van die Ou Testament is narratiewe wat die geskiedenis van Israel en Juda vanuit 'n bepaalde teologiese perspektief vertel. In die Nuwe Testament is die briewe van Paulus gerig aan gemeentes soos Rome en Galasië wat ontstaan het in die eerste eeu na Christus. Bybelskrywers maak gebruik van 'n taal 
(Hebreeus, Aramees en Grieks) en literêre tegnieke eie aan hulle tyd. Dit is alles getuienis dat die Bybel nie 'n a-historiese boek is wat "direk kommunikeer" nie. Die Bybel is veel eerder 'n boek wat in die geskiedenis ontstaan het en wat in die eerste plek gerig was op hoorders en lesers in 'n bepaalde histories aanwysbare tyd, soos byvoorbeeld die tyd van die ballingskap of die na-ballingskapstyd of 'n gemeente binne die eerste eeu na Christus.

Die eerste vraag wat gevra moet word, is wie bepaal watter tekste sogenaamd direk kommunikeer. Daar is Bybellesers (gelowiges) wat sonder meer oortuig is dat tekste in die Bybel direk met hulle kommunikeer dat die doodstraf 'n godgegewe opdrag vir alle tye is, dat homoseksuele persone 'n gruwel voor God is, dat vroue nie in die besondere ampte van ouderling, diaken of leraar toegelaat mag word nie, dat vroue hoede moet dra in 'n erediens, dat die bediening van Nagmaal aan kinders verbied word, ensovoorts. Hierdie meer respektabele voorbeelde kan aangevul word met belaglikhede, wat soms aan die banale grens.

Namate ons verder wegbeweeg van die ontstaanstyd van die Bybel en die historiese en kulturele gaping tussen ons as hedendaagse Bybellesers en die teks van die Bybel al groter word, word die aantal tekste wat "direk kommunikeer" sekerlik tog ook al minder. Daar moet liewer nie onderskeid gemaak word tussen tekste wat direk kommunikeer en tekste wat dit nie doen nie. Alle tekste in die Bybel word literêr en/of histories tot 'n mindere of meerdere mate geïnterpreteer. Selfs die tekste wat ons meen sogenaamd direk kommunikeer moet nog steeds onderwerp word aan eksegetiese ondersoek om die seggingskrag van die teks te bepaal. Wanneer die liefdesgebod van Jesus byvoorbeeld gehoor word, sal dit loon om te vra wát presies bedoel word met liefde vir God en die naaste met hart en siel en verstand. In die bekende Psalm 23 roep die beeld van die herder die idee van versorging op, maar in die $\mathrm{Ou}$ Nabye Ooste was 'n herder ook soms 'n metafoor vir 'n koning, sodat die beeld van herder in Psalm 23 ook die betekenisdimensie van "heers" kan hê.

\subsection{Enkele kleiner opmerkings}

Soms is Verster onduidelik en eintlik onverstaanbaar in sy argument. Verster (2005:729) skryf byvoorbeeld: "Die Ou Testament word dikwels gebruik om te sê dat God wispelturig is, of dat God van plan verander, of dat God nie trou aan sy beloftes is nie. Indien daar egter in die lig van God as primêre outeur van 'n bepaalde vorm van outeursintensie sprake kan wees, kan gesien word dat baie van 
hierdie tekste eintlik saamval met die onderliggende uniekheid en heiligheid van Jahwe, die Here wat onverdeelde trou aan Homself eis. Hierdie siening mond uiteindelik uit in die verlossing in Jesus Christus." Hierdie soort formulering roep meer vrae as antwoorde op. Word die Ou Testament dikwels(!) gebruik om te sê dat God wispelturig is, of dat Hy van plan verander, of dat God nie trou is aan sy beloftes nie? Hierdie vrae word gevra omdat daar geen verwysings na relevante literatuur gegee word nie. Dit is nie duidelik op watter manier daar gesien kan word hoe baie van die tekste (watter tekste?) "eintlik saamval met die onderliggende uniekheid en heiligheid van Jahwe" as daar maar net rekening gehou word met "'n bepaalde vorm van outeursintensie" nie.

Hoe die nuwe perspektief op God se handelinge in die wêreld wat die boek Job bied, saamhang met die Deuteronomis se perspektief, en wat in daardie konteks verstaan moet word (Verster, 2005:729), kon met groter helderheid nader verduidelik word. Wat presies is die samehang tussen die boek Job (as deel van die wysheidsliteratuur van die Ou Testament) en die Deuteronomis se perspektief (wat normaalweg verstaan word as deel van die historiese narratiewe) van die Ou Testament, veral as daar aanvaar word dat die wysheidsliteratuur onafhanklik van die heilstradisies van Israel ontstaan het?

Die skopiese lyn wat Verster (2005:730) in navolging van Heyns meen om in die Bybel te vind, is nie sonder probleme nie. Kan 'n mens regtig sê dat die verskillende boeke in die Bybel een groot loflied(!) oor God in die wêreld is, wanneer die aakligste tonele hulle afspeel in die boek Rigters, of die klaagpsalms of die skeptiese vrae van die wysheidsliteratuur (Prediker), of die profete (Habakkuk) se vrae oor God se bestuur van die wêreld gelees word? Is dit nie so 'n veralgemening van dit wat in die Bybel staan, dat dit eintlik 'n niksseggende stelling word nie?

Die organiese inspirasieteorie bly vir Verster (2005:730), ten spyte van 'n hele artikel wat ek wy aan die ontoereikendheid van bestaande inspirasieteorieë, tog nog 'n ruim teorie. Hy weerspreek homself egter twee sinne verder, as hy sê dat dit "nie ontken kan word dat daar besondere diepgaande probleme met betrekking tot die verstaan van die Skrif en die inspirasie van die Skrif bestaan nie ..." (Verster, 2005:730). Klaarblyklik is die organiese inspirasieteorie tog nie so ruim as wat Verster aanvanklik vermoed het nie.

In die voorlaaste paragraaf het Verster (2005:731) dit oor die belangrikheid van voorveronderstellings. Hy laat egter na om sy eie 
voorveronderstellings uiteen te sit. In sy slot is hy ook in teenspraak met homself. Aan die een kant is die uitgangspunt "dat God in sy majesteit die Bybel geïnspireer het en ook as auctor primarius optree, nie vals te bewys nie". Aan die ander kant is die belydenis dat God werklik in die Skrif aan die Woord kom, onbewysbaar (Verster, 2005:731).

\section{Slot}

Verster slaag nie daarin om my kritiese argumente teen bestaande inspirasieteorieë te weerlê nie. Hy gee geen aandag aan die problematiek van verskillende kanons of die problematiek van inspirasie en vertaling nie. Teenoor my standpunt van die onhoudbaarheid van 'n autographon of grondteks, handhaaf hy steeds die standpunt van 'n grondteks of bronteks.

Verster neem kennis van my kritiek teen die bestaande inspirasieteorieë, maar slaag nie daarin om my besware te weerlê of met 'n alternatief vorendag te kom nie. Die status quo bly dus die antwoord vir Verster.

\section{Geraadpleegde bronne}

BERKOUWER, G.C. 1967. De heilige Schrift. II. Kampen: Kok. (Dogmatische Studien.)

CALVIJN, J. s.a. Institusie of onderwijzing in de Christelijke godsdienst. Derde deel, Bevattende Boek IV. Delft: Meineda. (Vertaling van A. Sizoo.)

ELLIGER, K. \& RUDOLPH, W., Reds. 1984. Biblia Hebraica Stuttgartensia. Stuttgart: Deutsche Bibelgesellschaft.

GUTHRIE, D. 1981. New Testament theology. Leicester: InterVarsity.

NEL, P. 2003. Die Bybel: teks en ondermyning. Hervormde Teologiese Studies, 59(3):881-897.

NÜRNBERGER, K. 1975. Sistematiese teologie. Genadendal: Genadendalse Drukkery. (Teologiese Boekreeks, no. 20.)

SNYMAN, S.D. 2003. Oor die inspirasie van die Bybel - 'n Perspektief van 'n Ou Testamentikus. Verbum et Ecclesia, 24(2):459-473.

THERON, P.F. 2002. Die oudheid van die letter en die nuutheid van die Gees: enkele opmerkings oor die Skrif as lewende Woord. (In Tolmie, D.F., red. Essentialia et Hodierna, Oblata P.C. Potgieter. Bloemfontein: Universiteit van die Vrystaat. p. 150-168.) (Acta Theologica Supplementum, 3.)

VERSTER, P. 2005. Die dood van die outeur en die inspirasie van die Bybel: in gesprek met P.J. Nel en S.D. Snyman. In die Skriflig, 39(4):715-732. 


\section{Kernbegrippe:}

historiese lees

inspirasie van die Bybel

literêre lees

vertalings van die Bybel

\section{Key concepts:}

historical reading

inspiration of the Bible

literary reading

translations of the Bible 